\title{
English Self-Assessment Based on Pluralism in Preventing Radicalism
}

\author{
Santi Andriyani,santi@unisnu.ac.id, UNISNU, Jepara, Indonesia \\ Hayu Dian Yulistianti,hayu@unisnu.ac.id, UNISNU, Jepara, Indonesia \\ Nusrotus Sa'idah, nusrotus@unisnu.ac.id, UNISNU, Jepara, Indonesia
}

\begin{abstract}
The practice of radicalism in Indonesia has increased among all age groups, including adolescents. The study found that adolescents or the young generation are mostly affected by radicalism and extremism. This study aims to find out the implementation of English Self-Assessment Based on Pluralism in Preventing Youth Radicalism. This study uses a descriptive analysis method. The instrument of this study is the students' self-assessment worksheet focused on pluralism materials. The findings show that by implementing the English Self-Assessment rubric, the religious understanding of the students is a good criterion.

Keywords: English self - assessment, radicalism, descriptive analysis method
\end{abstract}

\section{INTRODUCTION}

One of the crucial aspects that must be prepared by teachers is the assessment technique. Assessment is important in the teaching and learning process to know the learning outcomes of students. (Ministry of Education, 2006) states that one of the objectives of the assessment is to describe the progress of the development of processes and outcomes of students.

The result of students' assessment should conduct the students' achievement on the cognitive aspect, affective aspect, and psychomotor aspect. One study found that there are still some teachers who only developed the cognitive aspect of learning and overrode the affective aspect and psychomotor aspect. When the teachers only measure the cognitive aspect, the education system in Indonesia will perform under average. The low quality of education systems in 2009 needed to improve in whole aspects of learning so that this nation can increase the education system among other nations in this global era. Therefore, the teacher should apply mastery learning and authentic assessment system.

One authentic assessment model that should be used by the teacher is self-assessment. (Kunandar, 2012) suggests that self-assessment is an assessment technique by asking students to express their strengths and weaknesses in the context of attitude competencies, both spiritual attitudes, and social attitudes. (Widoyoko, S, 2014) states that self-assessment is a valuation technique that provides opportunities for students to assess their work and abilities according to the experience they feel. Students are asked to assess themselves related to the process and their learning outcomes in a certain subject.

Self-assessment techniques can be used to measure three aspects of learning, namely cognitive, affective, and psychomotor. Self-assessment can also be used for all learning materials for the study of science, mathematics, religion, social, and language. It becomes a demand for teachers to use self-assessment as one of the assessment techniques in assessing students' outcomes in English language learning.

The advantages of self-assessment in learning can be found in other studies. The first study conducted by (Rohmah, S. N, Srijono, D, \& Hum, M, 2018), the result showed that 
most students stated that it was important to implement self-assessment on English subjects, because self-assessment helps them to know in what aspect they understood in the subject, what difficulties they face, and what should they do in the way of understanding the material. Another study conducted by Ismail \& Hamid (2012) stated that the implementation of selfassessment could improve the teaching and learning process through participation and class involvement. Besides, EFL students also said that the technique was useful and interesting. Furthermore, a study conducted by Baleghizadeh, S \& Masoun, A, (2014) states that students got some advantages by doing self-assessment. Therefore, EFL students are more oriented in learning through the implementation of self-assessment during the teaching and learning process.

This technique of self-assessment is important to be applied by the teacher because the social behavior of teenagers tends to be more self-centered or egoistic, either affected radicalism and extremism. It is supported by a study conducted by Darmawati, H \& Abdullah, T, (2016) in students' responses of Madrasah Aliyah (MA) students toward religious radicalism. The results showed that some of the students were affected by radicalization. Radicalism is not always about physical violence, but it could be an ideology of thought, massive campaigns, and ways to change the mainstream can also be classified as radical attitudes (Mulyadi, 2017).

One of the ways to prevent a rise of radicalism towards students or adolescents is applying values of pluralism, which is integrated into the learning process and the assessment technique. Pluralism is a belief that reality consists of diversity (race, ethnicity, religion, language) in society. This diversity can be accepted among each other and living peacefully so that it is created the safety for humanity (Azra, 2005). Based on the phenomena above, it can be concluded that it is important to conduct a study on English Self-Assessment Based on Pluralism in Preventing Youth Radicalism.

\section{METHOD}

The method of this study used descriptive analysis. Therefore, to find out how far students understand radicalization in a text, researchers tried to analyze the results of students' self-assessment rubric in preventing youth radicalism.

The object of this study is learning outcomes through pluralism-based self-assessment. The researcher tried to observe the learning process and used in English self-assessment based on pluralism.

The data collection technique used in this study was observation and document recorded. The researcher did observation by using the observation form. This observation used to find out the English teaching and learning process in preventing radicalism for students. By using the observation form, the researcher tried to observe the teaching and learning process using the English text and self-assessment rubric then describe it. Next, to find out students' understanding of the concept of pluralism, the researcher analyzed and conducted the data from self-assessment rubric and reading texts, which contains pluralism values. The self-assessment rubric was developed from English texts given to the students, which focused on pluralism values in preventing radicalism. The rubric was developed by determining the criterion of assessment used and by formulating the assessment format. 


\section{RESULTS AND DISCUSSION}

Based on the objective of the research that is to find out the results of the English SelfAssessment Based on Pluralism in Preventing Youth Radicalism, the researchers applied the English learning on reading comprehension to 48 students.

The researcher gave the text with its exercises to each student then they read the text individually and analyzed the text. In arranging classroom management, the researchers used the Focus Group Discussion (FGD) method by dividing it into several groups. Each group accompanied by researchers analyzed the text, then discussed it after the students understand the text well.

The way in preventing the radicalization in this study was analyzed through selfassessment that did by the students after reading the text. The self-assessment contains various statements related to the text given either related to the concept of radicalism. They rarely do the result of self-assessment analysis on students' activities in radicalization. The students rarely did defame, insulting people, humiliate other people's religion and their beliefs. Students rarely did bad activities, sin, and violate religious rules. Another side, the students respect the beliefs and religions of others. They also obey the rules of their religion, treat others well even with different backgrounds. Here is the self-assessment rubric of students:

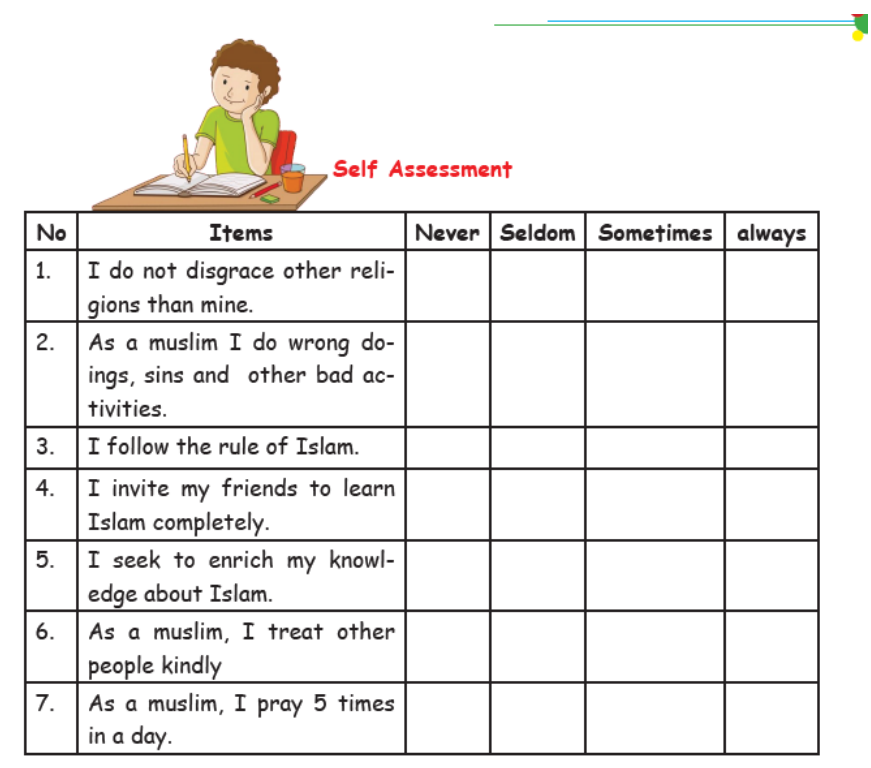

Figure 1. Self-Assessment Rubric focused on attitude and psychomotor aspects

The second self-assessment rubric based on the text entitled "Islam is For Ever Peace" is to find out students' religious understanding which related to the understanding of radicalism. The analysis of self-assessment showed that the students' religious understanding is a good criterion. The analysis showed that students understand well about the concept of Islam, which loves peace, not an anarchist religion. Students also understand well that religion is a life controller to do good deeds. The following is the form of self-assessment. 


\begin{tabular}{|l|l|l|l|l|l|}
\hline No & \multicolumn{1}{|c|}{ Items } & poor & fair & good & Excellent \\
\hline 8. & $\begin{array}{l}\text { I understand if I do good } \\
\text { deen I will be successful in } \\
\text { the hereafter. }\end{array}$ & & & \\
\hline 9. & $\begin{array}{l}\text { I understand the concept of } \\
\text { Islam as a peace religion }\end{array}$ & & & & \\
\hline 10. & $\begin{array}{l}\text { I understand Islam can con- } \\
\text { trol my life }\end{array}$ & & & \\
\hline
\end{tabular}

Figure2. Self- assessment rubric focused on the cognitive aspect

Based on the findings above, the integration of English text with pluralism is important in order to make students understand pluralism to prevent the radicalism of youth.

Reading comprehension is appropriate for the integration of English text with the values of pluralism. By applying reading comprehension, students will be able to understand the context of the text. According to Tarigan \& Henry G (2008), reading is a process to get the information from the writer through the written language. Dalman (2013) stated that reading is an activity or cognitive process that seeks to find various information contained in writing. This situation means that reading is a process to understand the contents of the reading text. Whereas reading comprehension is interpreted as a process of earnest reading to obtain meaning or the essence of a reading (Rahayu, R, Riyadi, A, \& Hartati, T, 2018).

In understanding a reading text based on pluralism, students not only understand textually, but students must be able to understand text information implicitly as the inferential understanding of students. Inferential understanding is the ability to understand information that is expressed indirectly (implied) in the text. Understanding text inferentially means understanding what is implied by information expressed explicitly in the text. In this case, the reader uses information expressed explicitly in the text, background knowledge, and integrated personal experience to make guesses or hypotheses (Burns \& Hairuddin, 2008).

Based on the findings above, the researchers concluded that authentic assessment through the self-assessment model in English reading based on the values of pluralism has a positive impact on preventing youth radicalism.

(Shofiyah, H, 2013) stated that self-assessment is students assessing themselves. Assessment with self-assessment techniques involves students both in giving an assessment and accepting an assessment. The advantages of the use of self-assessment include: growing students' confidence because they are given the confidence to judge themselves. Second, increasing students' understanding of their strengths and weaknesses. Third, train the students to be honest.

\section{CONCLUSION}

The strategies and techniques how to prevent radicalism practices among youth using English self-assessment are a) implementing English self-assessment based on the values of pluralism which was done by applying reading comprehension through the focus group discussion method; b) improving students' understanding of reading text-based on pluralism values, by using the technique of reading comprehension namely inferential understanding. Next, based on the result of students' self-assessment analysis showed that the religious 
understanding of students focused on pluralism values is good criteria. The implication of further research is needed to use the experimental method so that the result of the research on preventing radicalism through English learning.

\section{REFERENCES}

Baleghizadeh, S, \& Masoun, A. (2014). The Effect Of Self-Assessment On EFL Learners' Goal Orientation. Iranian Journal Of Applied Linguistics, 17(1), 25-48.

Dalman. (2013). Keterampilan Membaca. Jakarta: PT Rajagrafindo Persada.

Darmawati, H, \& Abdullah, T. (2016). Respon Siswa Madrasah Aliayah Terhadap Radikalisme Di Makasar. Sulesana, 10(1), 19-48.

Hairudin. (2008). Pembelajaran Bahasa Indonesia. Jakarta: Direktorat Jendral Pendidikan Tinggi Departemen Pendidikan Nasional.

Kunandar. (2012). Langkah Mudah Penelitian Tindakan Kelas Sebagai Pengembangan Profesi Guru. Jakarta: PT Rajawali Press.

Mulyadi. (2017). Peran Pemuda Dalam Mencegah Paham Radikalisme. Seminar Nasional 20 Prgram Pascasarjana Universitas PGRI Palembang, 249-255.

Rahayu, R, Riyadi, A, \& Hartati, T. (2018). Keterampilan Membaca Pemahaman Dengan Metode Pq4r (Preview, Question, Read, Reflect, Recite, Review) Siswa Sekolah Dasar Kelas Tinggi. Jurnal Pendidikan Guru Sekolah Dasar, 3(2), 46-56.

Rohmah, S. N, Srijono, D, \& Hum, M. (2018). The Students' Perception On Self-Assessment In English Language Subject At The Eighth Grade Of Junior High School 01 Tawangmangu. Doctoral Dissertation, Universitas Muhammadiyah Surakarta.

Shofiyah, H. (2013). Penerapan Self Assesment (Penilaian Diri) Pada Kegiatan Praktikum Untuk Meningkatkan Hasil Belajar Siswa Kelas X Sman 1 Sidayu. Inovasi Pendidikan Fisika, 2(3).

Sugiyono. (2009). Metode Penelitian Kuantitatif, Kualitatif Dan R\&D. Bandung: Alfabeta.

Sumarno, A. (2011). Penilaian Diri (Self Assesment) Dalam Pendidikan Berkarakter. ELearning Unesa.

Tarigan, \& Henry, G. (2008). Membaca Sebagai Suatu Keterampilan Berbahasa. Bandung: Angkasa.

Widoyoko, S. (2014). Evaluasi Program Pembelajaran. Yogyakarta: Pustaka Pelajar. 